\title{
Falkeid, Unn.
}

The Avignon Papacy Contested: An Intellectual History from Dante to Catherine of Siena.

Cambridge, MA: Harvard University Press, 2017. Pp. 269. ISBN 978-0-67497184-4 (hardcover) US\$49.95.

A specialist of Trecento literature and the history of ideas, Unn Falkeid's The Avignon Papacy Contested focuses on critics of the Avignon papacy (1309-77). Their names reveal the literary giants of the fourteenth century: Dante, Marsilius of Padua, William of Ockham, Petrarch, and female saints: Bridget of Sweden and Catherine of Siena. Their attacks were mostly centred on the popes' absolutist goals, and Falkeid's stated aim is to investigate, analyze, and contextualize this criticism. Unfortunately, her argument is flawed from the start because she assumes a direct connection between Boniface VIII's bull Unam sanctam, which granted the pope spiritual supremacy over the world and thus put temporal leaders below him, and the Avignon popes' vision of their own authority. No pope in Avignon claimed "absolute jurisdiction and the papacy's swift increase in prosperity and secular power" (13). They did not set standards for the Renaissance (173). Avignon popes reacted to crises and responded to secular encroachments. They were sound administrators and good bureaucrats.

Falkeid distinguishes herself from the field by suggesting that instead of reading these papal critics as mirrors of their political environment, much could be learned from treating them as engaged motivators or instigators for changes. She wants to include them in the list of medieval political scientists; address them together as a cohort, with Avignon as political backdrop.

Falkeid sets the stage in her introduction by mentioning the Franciscan Apostolic Poverty issue without fully discussing it. Details are not introduced until pages 78-80. Unfortunately, the discussion around Apostolic poverty is central to her first three authors. Saint Francis's commitment to poverty was absolute. In 1279 Pope Nicholas III facilitated the Franciscans' adherence to poverty by stating that Christ and the apostles held no individual or communal possessions; they simply used property. Henceforth, Franciscans had usus facti of goods, while the church possessed them. Still, a minority of Franciscans, the Spirituals, believed in total poverty, and in a sense disobeyed the pope. The break occurred during John XXII's rule. John condemned absolute poverty in 
the name of obedience (that could be his claim at plenitudo potestatis), and abrogated Nicholas III's bull. His next step was to grant Franciscans the right of ownership. Regardless of general recriminations, John shut down any further discussions. The theological argument turned political when emperors chose to side with papal critics.

The book's six chapters begin with a discussion of Dante's Paradiso VI and his Monarchia, followed by Marsilius of Padua's Defensor pacis. Using the late fifth-century Gelasian principle of the two separate swords, spiritual and temporal, Falkeid articulates how Dante criticism touched the "French" papacy's claims on the temporal and plenitudo potestatis. For Dante, a papacy controlled by greed (cupiditas) failed to adhere to the Gelasian principle of separation. Falkeid's close analysis of the texts does not demonstrate how and where the Avignon pope fits within her argumentation. The fact that the papacy condemned the work after Dante's death (according to Boccaccio), because it was perceived to defend Ludwig of Bavaria's coronation, blurs her argument. It seems that Dante's criticism attacked the papacy, in general, regardless of its location, in Avignon or in Rome.

Marsilius of Padua is next, with his defense of Ludwig of Bavaria-again, located at the heart of the spiritual controversy. Falkeid considers Marsilius's Defensor pacis a direct attack on John XXII, and the inspiration for Ludwig's "deposition" of the Avignon pope and installation of his antipope. No historical evidence is offered; we simply get an analysis of some of Marsilius's ideas and a suggestion that Ludwig would have put them into practice. Similarly, Falkeid's treatment of William of Ockham's Breviloquium fails at demonstrating a direct link with the Avignon popes specifically. The brilliant Franciscan was enmeshed with the spiritual issue, visited Avignon, escaped it, and became headstrong against the pope's plenitudo potestatis. Frustratingly, Falkeid presents no evidence to support an Avignonese claim at plenitudo potestatis outside of her authors' claims. Still, Falkeid unwinds Ockham's intricate argument carefully.

Chapter 4 focuses on Petrarch, Cola di Rienzo, and Rome. Falkeid progresses from the theology of poverty to the "theology" of Rome. Critics of Avignon argued that the papacy belonged in Rome. Falkeid discusses the association and rapports between intellectual and political leaders, and their use of Rome-legitimating symbols. She chooses to ignore that it is the highly itinerant "Roman" papacy of the thirteenth century and not Avignon that defined "It is not the place that sanctifies the man, it is the man who sanctifies 
the place" (The Hostiensis). A papacy outside Rome was not unusual and had actually been rationalized. Still, Clement VI understood the economic advantages embedded with location when he granted Rome its jubilee in 1350 .

The last two chapters, dedicated to Bridget of Sweden and Catherine of Siena, argue that the women convinced Pope Urban V and Gregory XI, respectively, to return to Rome. While in both cases Falkeid analyzes the mystics' visions and utterances in themselves, she leaves me unconvinced that the popes actually moved back to Rome because the saints told them to do so. The evidence presented fails the challenge of historical evidence. Popes spent fortunes pacifying the Papal States-then returned to Rome once legates had succeeded, truces in the Hundred Years Wars held, and the situation in Provence turned dangerous. On the other hand, there is no doubt that these women were used politically. Urban VI's use of Catherine during the Schism is accepted; yet Falkeid does not question her miraculous discovery of writing with the initiation of the Schism.

While I applaud Falkeid's inclusion of the two saints in her study, and her contextualization of their writings within political theories, she fails in the end to demonstrate with tangible evidence that her protagonists drove, inspired, or moved history, or that they affected or were affected by the historical context-in large part because she never takes the historical context seriously. The work abounds with unsubstantiated statements and errors: papal nepotism flourished (17); Urban V's French cardinals were disloyal, and Gregory XI was the illegitimate son of Clement VI (19); Gregory XI died at Castel Sant'Angelo surrounded by a Roman mob (20); the seven Avignonese popes were lawyers (20); Cola's unification of Rome and Italy went against the interest of the papacy (118); the Avignon papacy was profoundly secular (169); the decades of the Avignon papacy were unstable (176); the legitimacy of the Avignon papacy was questioned (177). These, as well as Falkeid's usage of the word "antipope" in discussions of the Schism (171), are only a few among many examples.

JOËLLE ROLLO-KOSTER

University of Rhode Island 